\title{
Peningkatan Hasil Belajar Konfigurasi Elektron dengan Menggunakan KIT SELECTION (Smart Electron Configuration)
}

\author{
Anisa Fernanda ${ }^{1)}$, Eny Enawaty ${ }^{2)}$, Rahmat Rasmawan ${ }^{3)}$ \\ ${ }^{1)}$ Jurusan Pendidikan Kimia, FKIP Universitas Tanjungpura \\ ${ }^{2}$ Staf Pengajar Jurusan Kimia, FKIP Universitas Tanjungpura \\ ${ }^{3}$ Staf Pengajar Jurusan Kimia, FKIP Universitas Tanjungpura \\ anisafernanda@student.untan.ac.id
}

\begin{abstract}
This research was motivated by the low learning outcomes of students on the electron configuration subject matter at SMA Negeri 2 Sungai Raya. This research aims to determine whether there was a difference in student learning outcomes between those who were given learning using KIT Selection media and those not on the electron configuration subject matter. Quasi experimental in the form of pretest-posttest control group design in the type of this study. The sample of this study were $X$ IPA 2 as the control class and XIPA 3 as the experiment class. In experiment class, cooperative learning assisted by KIT Selection was given, whereas cooperative learning without KIT Selection was applied in control class. The result of U-Mann Whitney Test showed that the significant value of 0,004 $<0,05$. Based on this result, it can be concluded that there was differences in learning outcomes between those who were given learning using KIT Selection media and those not on the electron configuration subject matter. The result of the Effect Size KIT Selection is 1,01 which is categorized as high and has an effect on learning outcomes by $34,38 \%$.
\end{abstract}

Keywords :Learning outcomes, KIT Selection, Electron Configuration

This is an open access article distributed under the Creative Commons 4.0 Attribution License, which permits unrestricted use, distribution, and reproduction in any medium, provided the original work is properly cited. @2018 by author and Universitas Negeri Padang.

\section{PENDAHULUAN}

Pembelajaran kimia adalah pelajaran dengan banyak materi bersifat abstrak, contoh nya yaitu Struktur Atom. Materi kimia yang abstrak cenderung membuat siswa sulit mema hami pelajaran sehingga siswa tidak bisa belajar aktif. Proses pembelajaran yang dapat memper baiki hasil belajar harus menggunakan metode serta strategi untuk membuat siswa lebih aktif. Memvisualisasikan materi abstrak lebih tepatnya dapat menggunakan media pembelajaran.

Hal yang dibutuhkan untuk menunjang strategi pembelajaran satu diantaranya yaitu menggunakan media pembelajaran. Media pem belajaran dapat memberi kesempatan pada siswa untuk lebih aktif. Namun, pembelajaran kimia sering diberi pembelajaran yang masih berpusat pada guru sehingga masih ditemukan siswa yang pasif dalam proses belajarnya (Fitriani, 2017). Proses pembelajaran yang demikian juga terda pat di SMA Negeri 2 Sungai Raya.

Wawancara dengan siswa di SMA Negeri 2 Sungai Raya mengatakan bahwa metode yang digunakan pengajar dalam pembelajaran kimia hanya berupa metode ceramah dan media powerpoint. Pada materi Struktur Atom, pengajar menggunakan metode ceramah ketika mengajar di kelas. Metode ceramah membuat siswamengalami kesulitan belajar materi yang bersifat abstrak karena tidak adanya sesuatu yang bisa diamati secara langsung dari materi tersebut sehingga diperoleh hasil belajar yang rendah. Selain itu, hasil wawancara dengan guru kimia terkait hasil belajar siswa SMA Negeri 2 Sungai Raya mengatakan bahwamasih rendah. Hasil ulangan harian siswa dari 3 kelas menun jukkan siswa memperoleh nilai kurang dari KKM sebesar $67,3 \%$ dan siswa yang memper oleh nilai lebih dari 70 sebesar $32,7 \%$. Rendah nya hasil belajar disebabkan karena siswa sulit membayangkan sifat abstrak konfigurasi elektron berupa orbital-orbital, pengisian elektron dalam orbital dan sebagainya. Guru mengajar siswa dengan menggunakan istilah-istilah seperti orbital, sub orbital atau sub kulit dan kulit yang membuat siswa bingung dengan perbedaan setiap istilah tersebut.

Kesalahan peserta didik sebagian besar terdapat pada sub materi konfigurasi elektron, yaitu kesalahan dalam menuliskan konfigurasi elektron pada unsur dalam tabel periodik (Mawarni, 2017). Kesalahan ini menjadi kesalahan konsep esensial yang dapat terjadi karena peserta didik tidak mengerti urutan konfigurasi 
elektron berdasarkan aturan Aufbau. Peserta didik tidak memahami tingkat energi berdasarkan aturan Aufbau. Pembelajaran yang demikian memerlukan strategi untuk memudahkan peserta didik memahami konsep yang abstrak seperti konfigurasi elektron dengan bantuan menggunakan media pembelajaran.

Solusi dari permasalahan yang ditwarkan adalah KIT Selection. KIT SELECTION (Smart Electron Configuration) merupakan inovasi media pembelajaran konfigurasi elektron yang terbuat dari bahan impraboard dan dikemas dalam bentuk KIT. Media KIT SELECTION divalidasi oleh satu dosen Pendidikan Kimia FKIP Universitas Tanjungpura dan satu guru kimia SMA Negeri 2 Sungai Raya sebelum diujikan ke siswa. Media KIT ini bisa digunakan secara berulang sehingga siswa dapat membuat konfigurasi elektron dengan nomor atom yang berbeda. Berdasarkan penelitian, media KIT bisa meningkatkan hasil belajar siswa, yaitu nilai KKM siswa yang diberi pembelaran mengguna kan KIT menjadi lebih tinggi pada pelajaran kimia (Khuzaimah, 2020).

KIT SELECTION dapat digunakan pada proses belajar siswa di kelas secara aktif dalam mempelajari aturan penulisan konfigurasi berdasarkan teori mekanika kuantum. Media pembelajaran KIT SELECTION dapat meningkatkan kemampuan komunikasi peserta didik melalui diskusi dengan teman satu kelompok, presentasi dan tanya jawab. Harapan peneliti, dengan adanya KIT Selection ini dapat membantu siswa dalam memvisualisasikan materi kimia yang bersifat abstrak sehingga siswa memiliki motivasi belajar.

Penelitian ini bertujuan untuk mengetahui apakah terdapat perbedaan hasil belajar siswa yang diberi pembelajaran berbantuan media KIT SELECTION dengan pembelajaran tanpa media KIT SELECTION. Tujuan lain dari penelitian adalah untuk mengetahui pengaruh media KIT SELECTION dalam pembelajaran.

\section{METODE PENELITIAN}

Penelitian ini merupakan jenis penelitian eksperimen dan desain yang digunakan Quasi Eksperimental jenisnya Desain Non-equivalent Group pretest-posttest. Pada penelitian ini menggunakan 2 kelompok yang diberikan perlakuan berbeda. Desain penelitiannya dapat dilihat pada Tabel 1.
Tabel 1. Desain Non-Equivalent Group PretestPosttest

\begin{tabular}{|l|c|c|c|}
\hline \multicolumn{1}{|c|}{ Kelompok } & Pretest & Perlakuan & Posttest \\
\hline $\mathrm{A}($ Eksperimen $)$ & $\mathrm{P}_{1}$ & $\mathrm{X}_{1}$ & $\mathrm{P}_{2}$ \\
\hline $\mathrm{B}($ Kontrol $)$ & $\mathrm{P}_{1}$ & $\mathrm{X}_{2}$ & $\mathrm{P}_{2}$ \\
\hline
\end{tabular}

$\mathrm{P}_{1}$ merupakan hasil belajar sebelum diberi kan pembelajaran (treatment) dan $\mathrm{P}_{2}$ nilai setelah diberikan pembelajaran (treatment). $\mathrm{X}_{1}$ mendapatkan model pembelajaran Cooperative Learning berbantuan media KIT Smart Electron Configuration. Sementara itu $\mathrm{X}_{2}$ dengan pembelajaran Cooperative Learning tanpa menggunakan KIT Selection.

Populasi penelitian ini adalah seluruh peserta didik kelas X SMA Negeri 2 Sungai Raya tahun ajaran 2019/2020. Sampel diambil meng gunakan teknik sampling kluster, yaitu kelas $\mathrm{X}$ MIPA 2 sebagai kelas kontrol dan X MIPA 3 sebagai kelas eksperimen. Pengumpulan data menggunakan tes tertulis dalam bentuk soal esai sebanyak 5 soal untuk tes awal dan 5 soal tes akhir. Tes dilakukan untuk mengetahui kemampuan peserta didik dalam menerima pelajaran yang telah dilakukan.

Pada instrumen, dilakukan analisis validitas yang dilakukan oleh 2 validator dan reliabilitas. Validator yang menganalisis berupa dosen kimia FKIP Universitas Tanjungpura dan guru kimia SMA Negeri 2 Sungai Raya. Hasil reliabilitas soal tes awal sebesar 0,66 dan hasil reliabilitas tes akhir sebesar 0,727 dengan kriteria "Tinggi".

Hasil tes siswa pada kedua kelas dianalisis menggunakan uji normalitas berbantuan SPSS Statistics 17. Kemudian melakukan uji U-Mann Whitney untuk menguji hipotesis.

\section{HASIL DAN PEMBAHASAN}

Hasil belajar dapat dilihat pada Tabel 2 . Tabel 2. Hasil Belajar Kelas Eksperimen dan Kontrol

\begin{tabular}{|l|c|c|c|c|}
\hline \multirow{2}{*}{ Aspek } & \multicolumn{2}{|c|}{ Eksperimen } & \multicolumn{2}{c|}{ Kontrol } \\
\cline { 2 - 5 } & $\begin{array}{c}\text { Pre } \\
\text { test }\end{array}$ & Post test & $\begin{array}{c}\text { Pre } \\
\text { test }\end{array}$ & Post test \\
\hline Rata-rata & 17,38 & 75,29 & 20,52 & 55,03 \\
\hline $\begin{array}{l}\text { Skor } \\
\text { tertinggi }\end{array}$ & 75 & 100 & 70 & 81,25 \\
\hline $\begin{array}{l}\text { Skor } \\
\text { terendah }\end{array}$ & 0 & 60,41 & 0 & 14,58 \\
\hline $\begin{array}{l}\text { Persentase } \\
\text { ketuntasan }\end{array}$ & $4,67 \%$ & $42,86 \%$ & $0 \%$ & $20,83 \%$ \\
\hline
\end{tabular}

Berdasarkan Tabel 2, ketuntasan pre test kelas kontrol $0 \%$, yaitu tidak ada siswa yang 
nilainya mencapai KKM dan ketuntasan kelas eksperimen $4,76 \%$, yaitu hanya 1 siswa yang nilainya mencapai KKM. Hal ini terjadi karena kedua kelas belum diberikan perlakuan pada proses pembelajaran. Hasil pre test pada kelas eksperimen dan kontrol tidak terlalu jauh berbeda, baik itu nilai rata-rata, standar deviasi maupun persentase ketuntasannya.

Ketuntasan post test kelas kontrol sebesar $20,83 \%$ yaitu terdapat 5 siswa yang nilainya mencapai KKM dan ketuntasan kelas eksperimen sebesar $42,86 \%$, yaitu terdapat 9 siswa yang nilainya mencapai KKM. Hasil post test tersebut menunjukkan rata-rata post test kelas eksperimen mengalami peningkatan lebih tinggi. Hasil uji pada data penelitian dapat dilihat pada Tabel 3.

Tabel 3. Hasil Uji Data Penelitian Kelas Eksperimen dan Kontrol

\begin{tabular}{|c|c|c|c|c|}
\hline \multirow{2}{*}{ Kelas } & \multicolumn{2}{|c|}{ Uji Normalitas } & \multicolumn{2}{c|}{ Uji Hipotesis } \\
\cline { 2 - 5 } & $\begin{array}{c}\text { Pre } \\
\text { test }\end{array}$ & $\begin{array}{c}\text { Post } \\
\text { test }\end{array}$ & $\begin{array}{c}\text { Pre } \\
\text { test }\end{array}$ & $\begin{array}{c}\text { post } \\
\text { test }\end{array}$ \\
\hline Eksperimen & 0,003 & 0,033 & \multirow{2}{*}{0,444} & 0,004 \\
\hline Kontrol & 0,002 & 0,042 & & \\
\hline
\end{tabular}

Kemampuan awal kelas eksperimen dan kelas kontrol diukur menggunakan data pre test. Perbedaan kemampuan awal dari kedua kelas sebelum diberikan perlakuan diuji menggunakan data pre test.

Kenormalan data diuji dengan bantuan program SPSS Statistic 17. Hasil uji menunjukkan kelas eksperimen memiliki Sig. 0,003 $<0,05$ dan Sig. 0,002 < 0,05 untuk kelas kontrol, maka kedua data tidak berdistribusi normal. Setelah itu dilakukan uji U-Mann Whitney untuk meng uji hipotesis dan menunjukkan nilai Sig.(2tailed) 0,444 >0,05, maka tidak ada perbedaan kemampuan awal pada kedua kelas sehingga untuk menentukan perbedaan hasil belajarmenggunakan data post test.

Hasil uji Shapiro-Wilk pada data post test kelas eksperimen, nilai Sig. 0,033<0,05 dan pada kelas kontrol, nilai Sig. 0,042<0,05, maka kedua data tidak berdistribusi normal. Uji hipotesis data posttest menunjukkan nilai Sig.(2tailed) 0,004 $<0,05$, maka terdapat perbedaan hasil belajar antara siswa yang diberi pembelajar an berbantuan KIT Selection dengan siswa yang tidak menggunakan KIT Selection pada sub materi konfigurasi elektron di SMA Negeri $2 \mathrm{Su}$ ngai Raya.
Pengaruh penggunaan media KIT SELEC TION dihitung menggunakan rumus Effect Size Glass's. Rumus Effect Size Glass's delta (dalam Backer, 2000) :

Keterangan :

$$
\Delta=\frac{\mathrm{M} 1-\mathrm{M} 2}{\mathrm{sdc}}
$$

$\Delta=$ effect size

M1 = rata-rata post test kelas eksperimen

M2 = rata-rata post test kelas kontrol

Nilai Effect Size yang diperoleh sebesar 1,010 dibulatkan menjadi 1,01 dengan kriteria Effect Size Glass's “Besar”.Persentase pengaruh penggunaan KIT Selection pada sub materi konfigurasi elektron terhadap hasil belajar di SMA Negeri 2 Sungai Raya sebesar 34,38\%.

Grafik pada Gambar 1menampilkan perbe daan rata-rata hasil tes siswa sebelum diberikan pembelajaran dengan setelah diberikan pembe lajaran. Hasil penelitian menunjukkan bahwa kelas yang diberikan pembelajaran mengguna kan KIT Selection mengalami peningkatan hasil belajar. Hasil belajar yang berbeda pada kedua dapat terjadi karena proses belajar yang berbeda.

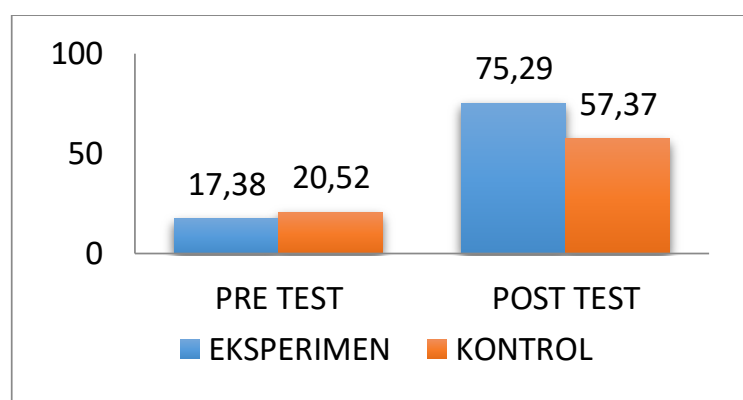

Gambar 1. Perbandingan Nilai Rata-rata Pre test dan Post test Siswa Kelas Eksperimen dan Kontrol

Proses pembelajaran pada kelas eksperimen dan kelas kontrol dapat dilihat pada Tabel 4.

Tabel 4. Proses Pembelajaran Kelas Eksperimen dan Kontrol

\begin{tabular}{|c|c|}
\hline Eksperimen & \\
\hline $\begin{array}{l}\text { - Siswa memulai } \\
\text { pembelajaran dengan } \\
\text { berdoa. } \\
\text { - Guru mengondisikan } \\
\text { kesiapan belajar } \\
\text { siswa. } \\
\text { - Guru menyampaikan } \\
\text { tujuan pembelajaran } \\
\text { - Guru menyampaikan } \\
\text { apersepsi tentang } \\
\text { konfigurasi elektron }\end{array}$ & $\begin{array}{l}\text { - Siswa memulai } \\
\text { pembelajaran dengan } \\
\text { berdoa. } \\
\text { - Guru mengondisikan } \\
\text { kesiapan belajar } \\
\text { siswa. } \\
\text { - Guru menyampaikan } \\
\text { tujuan pembelajaran } \\
\text { - Guru menyampaikan } \\
\text { apersepsi tentang } \\
\text { konfigurasi elektron }\end{array}$ \\
\hline
\end{tabular}




\begin{tabular}{|c|c|}
\hline 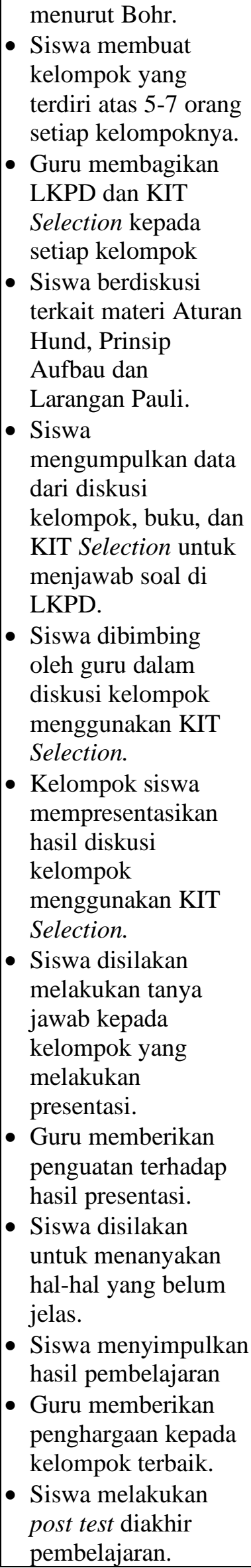 & 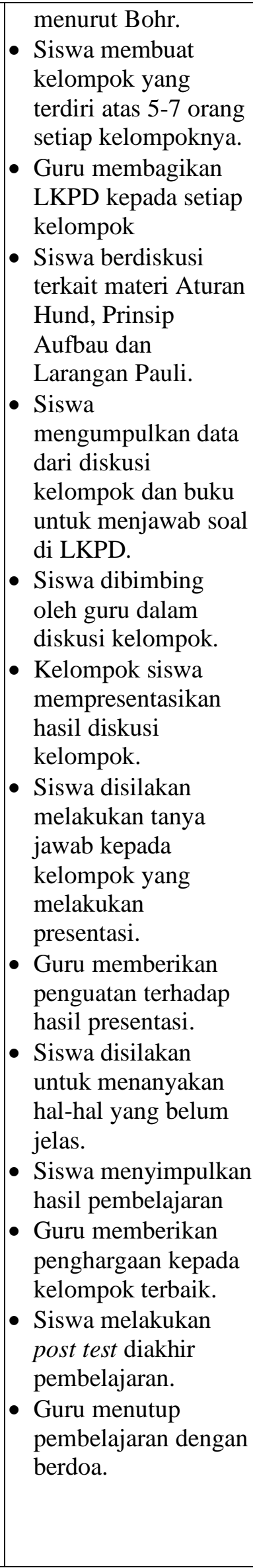 \\
\hline
\end{tabular}

\begin{tabular}{|c|}
\hline $\begin{array}{l}\text { - Guru menutup } \\
\text { pembelajaran dengan } \\
\text { herdoa }\end{array}$ \\
\hline
\end{tabular}

Kelas kontrol memiliki rata-rata pretest 20,52 dan tidak ada siswa yang memiliki nilai diatas KKM. Hasil belajar yang rendah ini terjadi karena kelas kontrol belum diberikan pembelajaran materi konfigurasi elektron berdasarkan teori mekanika kuantum.

Pembelajaran dilakukan pada pertemuan kedua. Kegiatan awal dimulai dengan berdoa, kemudian guru mengondisikan kesiapan belajar serta mengecek kehadiran siswa. Selanjutnya guru mengecek prasyarat pengetahuan dengan cara mengingatkan kembali tentang materi konfigurasi elektron menurut Bohr. Setelah itu guru menyampaikan apersepsi dan tujuan pembelajaran.Dengan adanya apersepsi dan tujuan pembelajaran, dapat membuat siswa menjadi tertarik mengikuti pembelajaran. Ketika siswa sudah tertarik untuk belajar, maka siswa juga bisa lebih semangat dan fokus ketika belajar. Selain itu, apersesi dapat menumbuhkan karakter inspiratif siswa yang terlihat melalui kegiatan pengamatan saat mengamati konfigurasi elektron menurut Bohr yang sulit digunakan apabila nomor atom unsur terlalu besar. Siswa dapat membayangkan bahwa ada cara lain untuk membuat konfigurasi elektron bernomor atom besar (Prasetyaningtyas, 2019).

Kegiatan inti dalam proses pembelajaran dimulai dengan guru menyajikan informasi, yaitu menjelaskan materi konfigurasi elektron. Ketika menjelaskan, guru meminta siswa membuat konfigurasi elektron unsur yang bernomor atom kecil dan besar menggunakan konfigurasi Bohr. Ketika siswa menuliskan konfigurasi dengan nomor atom kecil, tidak terdapat masalah, namun ketika siswa menuliskan konfigurasi yang bernomor atom besar, terdapat kekeliruan dimana siswa masih berpatokan pada rumus $2 \mathrm{n}^{2}$, yaitu rumus menentukan konfigurasi elektron berdasarkan Bohr. Kemudian, guru menjelaskan bahwa konfigurasi Bohr memiliki kelemahan, yaitu tidak bisa digunakan pada unsur yang bernomor atom besar.Konfigurasi elektron untuk unsur yang bernomor atom besar menggunakan konfigurasi elektron mekanika kuantum.

Selanjutnya guru memberikan tiap kelompok LKPD. Kemudian, masing-masing kelompok diminta untuk berdiskusi dengan anggotanya terkait Prinsip Aufbau, Azas Larangan Pauli dan Aturan Hund. Setelah itu setiap kelompok me 
ngumpulkan data dari diskusi kelompok dan buku untuk menjawab pertanyaan yang ada di LKPD.

Setelah diskusi kelompok, diminta 3 dari 5 kelompok untuk menyampaikan hasil diskusi di depan kelas. Kelompok yang menyimak boleh mengajukan pertanyaan ataupun memberi tang gapan. Kemudian guru memberi penguatan terhadap hasil presentasi dan siswa yang masih belum paham disilakan untuk bertanya. Pada saat presentasi, terdapat 2 kelompok yang pembagian tugasnya tidak merata. Hanya beberapa anggota yang melakukan presentasi. Selain itu, terdapat beberapa kekeliruan pada saat presentasi, seperti pada saat siswa memaparkan bunyi Prinsip Aufbau dengan Aturan Hund yang samasama berkaitan dengan tingkatan energi. Namun, siswa memberikan hasil yang cukup baik dengan menggunakan bahasa yang sederhana.

Pada akhir pembelajaran, guru memberikan penghargaan untuk setiap kelompok. Setiap kelompok memperoleh penghargaan, namun kelompok yang memberikan presentasi lebih baik akan mendapatkan penghargaan yang terbaik pula. Hal ini dlihat pada saat siswa melakukan presentasi. Kelompok terbaik yaitu kelompok yang bisa mengorganisir pembagian tugas secara merata serta dapat menjelaskan materi dengan baik. Berdasarkan hasil penelitian, pemberian penghargaan dapat meningkatkan prestasi belajar siswa. Semakin baik penghargaan yang diberikan, maka semakin baik pula hasil belajar siswa (Ritongga, 2019). Siswa kemudian me ngerjakan post test sebanyak 5 soal dan pembelajaran ditutup dengan doa.

Persentase ketuntasan posttest kelas kontrol sebesar 20,83\%, yaitu sebanyak 5 dari 24 siswa yang mencapai nilai KKM. Berdasarkan hasil Post test, beberapa kesalahan siswa yaitu pada soal nomor 4 dan 5, tepatnya pada bagian menuliskan konfigurasi elektron dan diagram orbital. Kesalahan siswa kelas kontrol dapat dilihat pada Gambar 5.

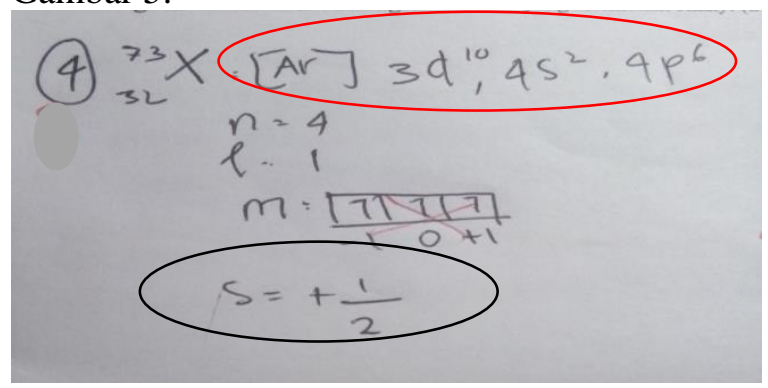

Gambar 2. Jawaban Siswa Kelas Kontrol
Lingkaran merahyang terdapat pada Gambar 2 menunjukkan bahwa siswa keliru menuliskan konfigurasi elektronnya, yaitu tidak berdasarkan pada Prinsip Aufbau tetapi berdasarkan jumlah kulit. Jawaban yang benar seharusnya ${ }_{32} \mathrm{X}=$ [Ar] $4 s^{2} 3 d^{10} 4 p^{2}$. Pada proses pembelajaran telah diberi pembelajarankan bahwa penulisan konfigurasi elektron bisa berdasarkan jumlah kulit dan berdasarkan tingkat energi. Namun, Prinsip Aufbau menggunakan tingkat energi. Kesalahan ini terjadi karena siswa lupa urutan tingkat energi berdasarkan Prinsip Aufbau. Selain itu, kesalahan utama pada jawaban siswa terletak pada penulisan konfigurasi elektronnya sehingga untuk menentukan bilangan kuantum nya juga salah. Jawaban yanag tepat untuk nomor 4 yaitu

${ }_{32} X: 1 s^{2} 2 s^{2} 2 p^{6} 3 s^{2} 3 p^{6} 4 s^{2} 3 d^{10} 4 p^{2}$

Diagram orbital $4 \mathrm{p}^{2}$

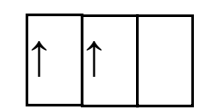

$4 p^{2}: \underline{n=4} \mathrm{l}=1 \mathrm{~m}=0 \mathrm{~s}=+1 / 2$

Kemudian pada jawaban yang di lingkar hitam menunjukkan bahwa siswa keliru menuliskan diagram orbital. Seharusnya jumlah elektron di dalam diagram orbital adalah 2 elektron bukan 3 elektron, karena diagram orbital terakhir dari ${ }_{32} \mathrm{X}$ adalah $4 \mathrm{p}^{2}$. Dalam proses pembelajaran telah dijelaskan cara pengisian elektron ke dalam orbital-orbital, namun masih terdapat kekeliruan ketika siswa menjawab soal. Kesalahan ini mungkin saja terjadi karena siswa kurang mengerti bahwa setiap orbital diisi oleh elektron sesuai dengan jumlah elektron dalam sub orbital.

Gambar 3 menunjukkan kekeliruan yang hampir sama seperti Gambar 2. Siswa keliru menuliskan konfigurasi elektron dan tidak mengisi elektron ke dalam diagram orbital. Kekeliruan ini mungkin terjadi karena siswa mengabaikan untuk mengisi elektron ke dalam orbital, sedangkan untuk menentukan bilangan kuantum magnetik, elektron harus diisi ke dalam orbital. 


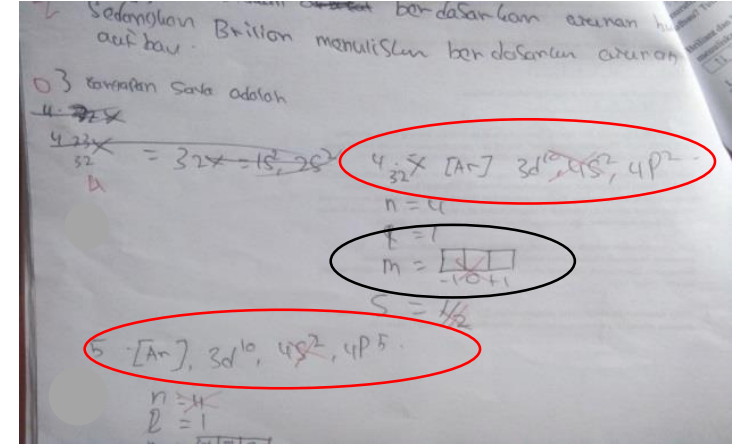

Gambar 3. Jawaban Siswa Kelas Kontrol

Diagram Aufbau merupakan urutan penulis an sub orbital berdasarkan pada tingkat energinya. Berdasarkan Gambar 2 dan Gambar 3, yang dilingkari warna merah, siswa masih keliru menuliskan konfigurasinya. Siswa cenderung menuliskan konfigurasinya berdasarkan pada kulitnya, yaitu urutan dari kulit terkecil ke kulit terbesar. Pengisian konfigurasi berdasarkan pada kulit tidak sesuai dengan Prinsip Aufbau yang mana pengisian elektron pada sub orbital berdasarkan pada tingkat energi. Siswa terbalik menuliskan konfigurasinya, dimana seharusnya $4 \mathrm{~s}$ dahulu, kemudian 3d, sehingga konfigurasi elek tron yang benar adalah ${ }_{32} \mathrm{X}=[\mathrm{Ar}] 4 \mathrm{~s}^{2} 3 \mathrm{~d}^{10}$ $4 \mathrm{p}^{2}$.

Aktivitas pembelajaran di kelas kontrol dapat berlangsung secara aktif dan siswa dapat membantu teman sekelompoknya. Namun, terdapat pula kelompok yang kurang aktif. Ini terlihat ketika pembelajaran berlangsung, dimana terdapat kelompok yang tidak antusias mempresentasikan hasil diskusinya.

Hasil wawancara dengan siswa di kelas kontrol, siswa mengungkapkan bahwa satu diantara kekurangan dalam proses pembelajaran adalah tidak adanya menggunakan media pembelajaran. Siswa merasa pembelajaran akan lebih menarik jika menggunakan media. Dengan adanya media pembelajaran akan membuat siswa tidak merasa bosan dan membantu ingatan mereka mengenai materi yang dipelajari. Namun, siswa masih bisa memahami sedikit materi pelajaran, karena pem belajaran dilakukan dengan diskusi kelompok. Pembelajaran dengan diskusi kelompok ini mem buat sesama teman kelompok saling bekerja sama. Kelas kontrol menerapkan pembelajaran kooperatif tanpa menggunakan KIT Selection.

Kelas eksperimen yaitu kelas X IPA 3 melakukan pretest pada pertemuan pertama. Hasil pre test kelas eksperimen memiliki ratarata 17,38 . Namun, terdapat 1 siswa yang tuntas pada saat pre test.Hal ini terjadi karena siswa tersebut sudah belajar mandiri di rumah sebelum dilakukannya pre test. Selain itu, berdasarkan informasi dari guru kimia yang bersangkutan mengatakan bahwa siswa ini juga memiliki nilai akademik dan nilai kimia yang bagus. Hasil belajar yang rendah ini terjadi karena kelas eksperimen belum diberi pembelajaran materi konfiguasi elektron berdasarkan teori mekanika kuantum.

Kegiatan inti dalam proses pembelajaran dimulai dengan guru menyajikan informasi, yaitu menjelaskan materi konfigurasi elektron. KIT Selection digunakan pada saat guru menyajikan informasi, yaitu guru menjelaskan carapenulisan konfigurasi elektron menggunakan teori mekanika kuantum.

Selanjutnya guru memberikan tiap kelompok LKPD dan KIT Selection. Masing-masing kelompok diminta untuk berdiskusi dengan anggotanya, kemudian mengumpulkan data dari diskusikelompok, buku dan KIT Selection untukmenjawab pertanyaan yang ada di LKPD menggunakan KIT Selection. Setelah berdiskusi, diminta 3 dari 5 kelompok untuk mempresentasikan hasil diskusi. Pada saat presentasi, setiap kelompok menggunakan KIT Selection untuk menjelaskan konfigurasi elektron berdasarkan Atu ran Hund, prinsip Aufbaudan Azas Larangan Pauli. Kelompok yang menyimak boleh bertanya ataupun memberi tanggapan.

Pada saat presentasi, setiap anggota kelompok terlihat membagi tugas. Ada yang menjelas kan Aturan Hund, Prinsip Aufbau dan Azas Larangan Pauli, dan ada yang memperagakan peng isian elektron berdasarkan masing-masing atur an penulisan konfigurasi elektron. Kemudian guru memberi penguatan terhadap hasil presentasi kelompok.

Post test dilakukan pada pertemuan kedua di akhir pembelajaran. Persentase ketuntasan kelas eksperimen 42,86\%. Jumlah siswa yang men capai KKM meningkat menjadi 9 siswa. Peningkatan ini dapat terjadi karena pembelajaran yang menggunakan media KIT Selection. Jawab an post test siswa di kelas eksperimen dapat dilihat pada Gambar 4.

Soal yang banyak salah adalah nomor 4 dan 5. Hal ini mungkin saja terjadi karena pada soal nomor 4 dan 5 merupakan soal yang cukup sulit. Siswa harus memahami Aturan Hund, Prinsip Aufbau dan Azas Larangan Pauli untuk bisa menjawab soal nomor 4 dan 5 . Kesulitan siswa dapat dilihat pada hasil post test yang menujukkan masih ada yang keliru menjawab soal nomor 
1 tentang Prinsip Aufbau. Terdapat 6 dari 21 siswa yang jawabannya masih kurang tepat mengenai Prinsip Aufbau. Oleh karena itu, jika siswa masih kesulitan pada soal nomor 1 me ngenai Prinsip Aufbau, maka siswa juga akan mengalami kesulitan untuk menjawab soal nomor 4 dan 5. Siswa di kelas eskperimen cukup banyak yang menjawab benar pada soal post test nomor 4 dan 5 jika dibandingkan dengan siswa kelas kontrol. Penggunaan KIT Selection pada saat pembelajaran membantu siswa dalam belajar.

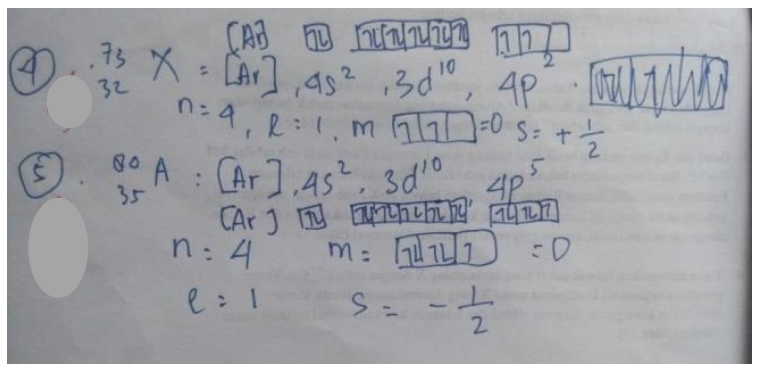

Gambar 4. Jawaban Post Test Siswa Kelas Eksperimen

KIT Selection digunakan untuk melengkapi media pembelajaran yang terdapat di sekolah. KIT Selection ini terdiri dari orbital, elektron, unsur-unsur gas mulia, tabel sistem periodik unsur, dan diagram Aufbau serta petunjuk penggunaan KIT Selection. Dengan KIT Selection, diharapkan dapat membantu siswa memahami materi konfigurasi elektron. Berdasarkan penelitian, media KIT berpengaruh dalam memotivasi siswa untuk belajar sehingga membantu siswa dalam memahami pelajaran.

Pada KIT Selection disediakan Diagram Aufbau. Diagram Aufbau merupakan urutan penulisan sub orbital berdasarkan pada tingkat energinya. Seperti yang terlihat pada Gambar 4, siswa di kelas eksperimen sebagian besar sudah benar menuliskan konfigurasinya. Sebelumnya, pada kelas kontrol banyak yang terbalik menuliskan konfigurasi, yaitu menuliskan 3d dahulu kemudian 4s. Padahal urutan yang benar yaitu 4 s terlebih dahulu kemudian 3d. Hal ini bisa terjadi karena pada KIT Selection diberikan diag ram Aufbau yang digunakan pada saat siswa berdiskusi dan menjelaskan hasil presentasi di depan kelas. Adanya diagram Aufbau membantu mengingatkan siswa untuk menuliskan konfigurasi berdasarkan pada tingkat energi yang rendah ke tinggi.

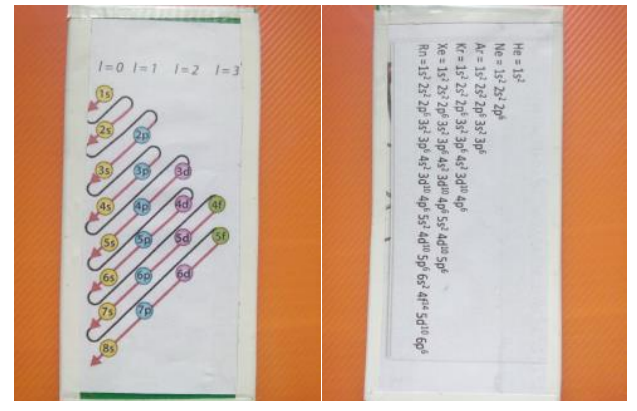

Gambar 5. Diagram Aufbau (Kiri) dan Konfigurasi Unsur Gas Mulia (Kanan)

Selain itu, KIT Selection juga menyediakan, orbital s, p d dan $\mathrm{f}$ diberikan pembedaan warnanya. Tujuan pembedaan orbital ini untuk membantu ingatan siswa ketika menggambarkan diagram orbital. Dengan adanya KIT Selection yang menyediakan orbital, harapannya dapat membantu siswa mengingat penulisan diagram orbital.

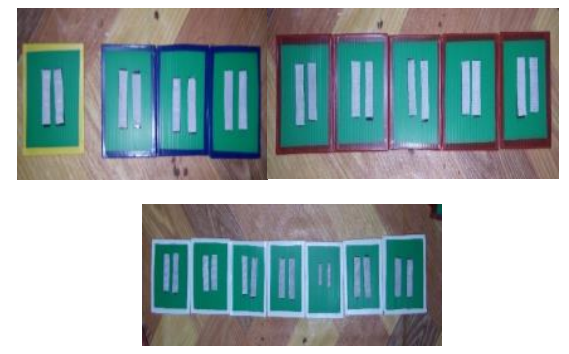

Gambar 6. Orbital s, p, d dan f

Hasil wawancara dengan siswa di kelas eksperimen, KIT Selection yang diberikan dapat membantu siswa dalam mengimajinasikan sifat abstrak dari konfigurasi elektron, sehingga menghindari adanya kesalahan. Dengan adanya media, siswa menjadi lebih mudah mengerti pelajaran. Selain itu, siswa merasa senang bisa belajar menggunakan media. Siswa mengatakan bahwa menuliskan konfigurasi elektron dengan bantuan media sangat menyenangkan. Suwaryantini, dkk (2014) dalam penelitiannya jugamenunjukkan bahwa media dapat membantu guru menjelaskan, sehingga siswa lebih mengerti dan memahami materi dan dengan adanya media pembelajaran membuat pembelajaran lebih menyenangkan.

Peningkatan hasil belajar kelas kontrol dari $0 \%$ menjadi20,83\% siswa yang tuntas pada sub materi konfigurasi elektron terjadi karena siswa diberikan model pembelajaran kooperatif. Sedangkan hasil belajar di kelas eksperimen meng alami peningkatan dari $4,76 \%$ menjadi $42,86 \%$ 
siswa yang tuntas pada sub materi konfigurasi electron karena diberi model pembelajaran kooperatif berbantuan KIT Selection. Hasil ini sejalan dengan penelitian (Gunawan, 2019) mengatakan bahwa hasil belajar kimia dapat memberi kan hasil yang lebih baik jika menggunakan KIT dalam pembelajaran kooperatif.

Peningkatan hasil belajar terjadi pada kedua sampel penelitian.Namun, kelas eksperimen memiliki peningkatan hasil belajar lebih besar. Nilai perhitungan Effect Size adalah sebesar 1,01 dengan kriteria Effect Size Glass's "Besar" dan persentase pengaruh penggunaan KIT Selection sebesar 34,38\%. Hal ini sejalan dengan penelitian (Khuzaimah, 2020), dimana hasil belajar siswa yang diberi pembelajaran menggunakan KIT mengalami peningkatan.

\section{KESIMPULAN}

Berdasarkan hasil penelitian tentang pengaruh KIT Selection (Smart Electron Configuration) pada sub materi konfigurasi elektron terhadap hasil belajar di SMA Negeri 2 Sungai Raya, disimpulkan bahwa(1) terdapat perbedaan hasil belajar siswa yang diberi pembelajaran berban tuan media KIT SELECTION dengan pembelajaran tanpa media KIT SELECTION,(2) pembelajaran dengan menggunakan KIT Selection berpengaruh sebesar 34,38 \% terhadap pening katan hasil belajar siswa kelas X IPA di SMA Negeri 2 Sungai Raya.

\section{DAFTAR PUSTAKA}

Becker, Lie, A. 2000. Effect Size (ES).(Online). (http://web.uccs.edu/lbecker/Psy590/s.ht m, diakses tanggal 5 Mei 2019).

Fitriani, Tuti Kurniati dan Raudhatul Fadhilah. 2017. Pengaruh Model Kooperatif Tipe Numbered Heads Together (NHT) Bersetting Problem Possing Terhadap Hasil Belajar Siswa Pokok Bahasan Stoikio metri Kelas X IPA SMA Negeri 8 Pon tianak. Ar-Razi Jurnal Ilmiah. Vol.5 No. 1.

Gunawan, Lalu Ardian., Sukib., Aliefman Hakim.2019.Pengaruh Model Pembelajaran Kooperatif Tipe Team Assisted Individualization (TAI) Berbantuan Study Card Terhadap Hasil Belajar Kimia. Chemistry Education Practice (jurnalfkip.unram.ac.id).

Khuzaimah, Dasopang. 2020. Pengembangan KIT Pembelajaran Dari Limbah Pada
Materi Ikatan Kimia Untuk Meningkat kan Motivasi dan Hasil Belajar Siswa SMA Kelas X. Jurnal Inovasi Pembe lajaran Kimia 2 (2), 115-120.

Mawarni, Ika, Husna Amalya Melati dan Lukman Hadi. 2017. Deskripsi Kesalahan Siswa SMAN 3 Pontianak dalam Menyelesaikan Soal Struktur Atom dan Sistem Periodik Unsur. Jurnal Pendidikan dan Pembelajaran. (online) (jurnal. untan.ac.id, 9 Desember 2018)

Prasetyaningtyas, Fitria Dwi.2019.Inovasi Model Quantum Learning Menggunakan Teori Apersepsi Berbasis Karakter Untuk Meningkatkan Kualitas Pembelajaran Mata Kuliah Pendidikan IPS SD. Elementary School Education Journal. Vol. 3 No. 2

Ritongga, Mariyatul Kubtiyah.2019.Pengaruh Pemberian Reward Dalam Proses Pembelajaran Terhadap Prestasi Belajar Siswa Kelas X Kompetensi Keahlian Akuntansi SMK Negeri 4 Padangsidimpuan Tahun Ajaran 2018/2019. Journal Education and Development. Vol. 7 No. 2.

Suwaryantini, Ni, Md., Sulastri dan Ni, Kt. Suarni. 2014. Pengaruh Media Kartu Berseri Melalui Model Terpadu Tipe Webbed terhadap Hasil Belajar Membaca Permulaan. E-Journal MIMBAR $P G S D$ Universitas Pendidikan Gane. 